\title{
Edukasi dalam Mewujudkan Masyarakat yang Sehat dan Cerdas di Masa Pandemic Covid 19
}

\author{
Irra Datik Pratiwi ${ }^{1 *}$, Mila Faila Shofa ${ }^{2}$ \\ ${ }^{12}$ Institut Islam Negeri Surakarta, Jl. Boulevard IAIN, Surakarta, Indonesia \\ *Corresponding Author Email: irradatik2@gmail.com, Telp: +6281575190070
}

Received: 13 November 2020; Revised: 24 February 2021; Accepted: 03 Maret 2021

\begin{abstract}
Abstrak: Persebaran virus COVID-19 meningkat semakin cepat melalui percikan dahak dan saluran pernapasan. Akan tetapi, masih sangat minim pemahaman dan kesadaran masyarakat Dusun Saren RT 11/ RW 02, Desa Saren, Kecamatan Kalijambe, Kabupaten Sragen yang mematuhi protokol kesehatan saat beraktivitas diluar rumah. Berdasarkan permasalahan tersebut, penulis melakukan kegiatan penelitian melalui dengan mengedukasi masyarakat setempat melalui edukasi protokol kesehatan, penyemprotan disenfektan, dan penanaman tanaman sehat, serta penyebaran poster. Penelitian ini menggunakan metode penelitian kualitatif dengan pendekatan etnografi. Subjek penelitian Masyarakat Dusun Saren RT 11/ RW 02, Desa Saren, Kecamatan Kalijambe, Kabupaten Sragen. Analisis data menggunakan analisis interaktif yang meliputi pengumpulan data, penyajian data, reduksi data dan penarikan kesimpulan. Hasil penelitian sesuai dengan pegalaman lapangan peneliti menunjukkan bahwa setelah diberikan edukasi COVID-19 masyarakat setempat mendapatkan pemahaman mengenai COVID-19, dapat menerima dan lebih memahami informasi mengenai langkah-langkah kewaspadaan dan pencegahan infeksi COVID-19, serta lebih waspada untuk mematuhi protokol kesehatan , seperti menggunakan masker saat bepergian dengan benar dan mencuci tangan atau memakai disenfektan setelah menyentuh benda-benda ditempat umum.
\end{abstract}

Kata Kunci: edukasi, masyarakat, sehat, cerdas, covid-19

\section{Education in Creating a Healthy Society and Smart During the Covid Pandemic 19}

\begin{abstract}
The spread of the COVID-19 virus is increasing rapidly through sputum sputum and the respiratory tract. However, there is still very little understanding and awareness of the people of Saren Hamlet RT 11 / RW 02, Saren Village, Kalijambe District, Sragen Regency who adhere to health protocols when doing activities outside the home. Based on these problems, the authors conducted research activities by educating the local community through education on health protocols, spraying disinfectants, planting healthy plants, and distributing posters. This research uses qualitative research methods with an ethnographic approach. The research subjects of Saren Hamlet RT 11 / RW 02, Saren Village, Kalijambe District, Sragen Regency. Data analysis used interactive analysis which included data collection, data presentation, data reduction and conclusion drawing. The results of the research are in accordance with the researcher's field experience showing that after being given COVID-19 education the local community gets an understanding of COVID-19, can receive and better understand information about precautionary measures and prevention of COVID-19 infection, and be more vigilant to comply with health protocols. such as wearing a mask when traveling properly and washing hands or wearing disinfectants after touching objects in public places.
\end{abstract}

Keywords: education, community, healthy, smart, covid-19

How to Cite: Pratiwi, I D, Shofa, M F. (2021). Edukasi dalam Mewujudkan Masyarakat yang Sehat dan Cerdas di Masa Pandemic Covid 19. JPPM (Jurnal Pendidikan dan Pemberdayaan Masyarakat), 8(1), 48-57.

Doi: https://doi.org/10.21831/jppm.v8i1.35761 


\section{PENDAHULUAN}

Pada saat ini seluruh warga di Indonesia dari berbagai wilayah manapun berada di masa pandemi Corona Virus Disease-19 (COVID-19). Coronavirus adalah sekumpulan virus yang dapat menyebabkan suatu penyakit pada hewan atau manusia. Hal ini sependapat dengan (WHO, $202 \mathrm{ob}$ ) bahwasannya coronavirus jenis baru ini dapat menyebabkan penyakit. Ada beberapa jenis coronavirus yang baru diketahui bisa menyebabkan infeksi saluran nafas pada manusia mulai dari batuk pilek hingga yang lebih serius. Virus tersebut seperti Middle East Respiratory Syndrome (MERS) dan Severe Acute Respiratory Syndrome (SARS) (Cao et al., 2020). Virus COVID-19 merupakan penyakit yang baru ditemukan oleh karena itu pengetahuan terkait pencegahannya masih terbatas. Kunci pencegahan meliputi pemutusan rantai penularan dengan isolasi, deteksi dini, dan melakukan proteksi dasar. Perjalanan penyakit dimulai dengan masa inkubasi yang lamanya sekitar 3-14 hari (median 5 hari). Pada fase berikutnya, virus dapat menyebar melalui aliran darah, diduga terutama pada jaringan seperti paru-paru, saluran cerna dan jantung. Gejala pada fase ini umumnya ringan. Setelah gejala awal maka akan terjadi gejala selanjutnya yang dialami pada empat sampai tujuh hari. Pada fase ini pasien masih demam dan mulai merasakan sesak napas, lesi di paru memburuk dan limfosit menurun. Sebagai pasien dikategorikan dalam gejala ringan apabila mengalami infeksi akut saluran napas tetapi tanpa komplikasi, kemudian disertai demam, merasa lelah lesu atau kurang tenaga, rasa kurang sehat secara umum, batuk, nyeri tenggorokan, sakit kepala, dan hidung bengkak disertai cairan dan lendir berlebih.

Hingga kini laju persebaran Corona virus Disease-2019 (COVID-19) meningkat semakin cepat melalui tetesan air liur atau keluar dari hidung ketika orang yang terinfeksi batuk atau bersin. Virus ini juga sangat berbahaya ketika menyerang tubuh manusia, tidak hanya menyebabkan infeksi saluran nafas melainkan juga dapat menyebabkan masalah fatal yaitu kematian. Dalam penularan virus ini yang pertama yaitu sistem pernafasan manusia yang menjadikan manusia menyebabkan gejala flu, batuk dan sedikit demi sedikit mengalami kesulitan dalam bernafas. Dan proses penyebaran virus Covid-19 ini dapat ditularkan melalui bersin, keringat dan kontak dekat dengan manusia yang sudah terinfeksi virus ini. Hal ini sesuai dengan penelitian dalam mempelajari SARS dan MERS dalam mengetahui sebab virus Corona masuk ke tubuh manusia.

Dilansir dari National Geographic, Senin (17/2/2020), Covid-19 memiliki genetik yang mirip dengan SARS. Dengan sebab itu, para penelit mempelajari SARS dan MERS untuk mengetahui perihal dari virus corona Wuhan. Virus menyebabkan gejala flu dan batuk serta akan mengalami sedikit demi sedikit kesulitan dalam bernafas. Virus ini biasanya menular saat orang yang terinfeksi batuk atau bersin, mengeluarkan cairan yang bisa menularkan kepada siapa saya yang berada didepannya atau yang pernah melakukan kontak dekat. Berkaitan dengan wabah SARS, Organisasi Kesehatan Dunia menyatakan bahwa penyakit ini menyerang paru-paru. Pasien yang sudah mengidap penyakit ini setelah sembuh paru-parunya tetap mengalami keruskan permanen (Amalia Zhahrina, 2020).

Upaya dalam mengatasi persoalan penyebaran COVID-19 ini pemerintah melakukan beberapa upaya pencegahan yang meliputi dari beberapa aspek kehidupan. Pertama dalam aspek pendidikan, pemerintah menerapkan pelaksanaan program belajar di rumah (Kemendikbud, 2020). Hal ini bisa melalui berbagai media berbasis internet maupun melalui media yang tidak berbasis internet (Amany \& Desire, 2020). Kedua dalam aspek kesehatan, pemerintah telah memberi edukasi kepada masyarakat mengenai pentingnya menjaga kebersihan dan kesehatan, pentingnya menggunakan masker saat bepergian dari rumah, melakukan isolasi mandiri bagi orang-orang yang mempunyai resiko lebih, serta memberikan panduan mengenai pencegahan penularan COVID-19 (Telaumbanua, 2020). Ketiga dalam bidang agama, pemerintah melalui Majelis Ulama Indonesia (MUI) telah memberikan fatwa terkait dengan pelaksanaan ibadah di masa wabah pandemi COVID-19 (Aji \& Habibaty, 2020). Hingga pada tingkat desa, pemerintah telah mengeluarkan protokol terkait relawan desa Lawan 


\section{JPPM (Jurnal Pendidikan dan Pemberdayaan Masyarakat), 8 (1), 2021 - 50}

Irra Datik Pratiwi, Mila Faila Shofa

COVID-19 (Kemendesa, 2020). Serta yang keempat dalam bidang sosial masyarakat, pemerintah membangun konsep mitigasi komunitas, berupa pembatasan jarak antar orang yang sedang berada di tempat umum atau memakai fasilitas umum, pengurangan frekuensi pertemuan yang berskala besar, hingga himbauan untuk melakukan suatu kegiatan atau hal apapun yang lebih baik dilakukan di rumah sendiri saja (Nasruddin \& Haq, 2020). Namun, meskipun pemerintah telah melakukan berbagai upaya diberbagai bidang kehidupan dalam menanggulangi penyebaran COVID-19, penambahan kasus positif COVID-19 di Indonesia semakin bertambah. Hal itu karena kurangnya pengetahuan tentang pandemi yang berkaitan dengan minimnya kesadaran masyarakat (WHO, 202ob). Hal ini diperkuat dalam penelitian yang dilakukan oleh windi mulyani yang menyatakan bahwa "Masih sangat minim pemahaman kesadaran masyarakat yang mematuhi protokol kesehatan saat beraktifitas di luar rumah" (Mulyani, 2020). Dengan begitu diperlukan penanganan (pencegahan atau pengobatan terhadap yang terkena infeksi COVID-19) kurang terintegrasi-interkoneksi dalam sistem pemerintahan di negara kita. Dari pusat sampai bagian paling bawah, yaitu desa (kampung). Hal ini sangat berbahaya karena penyebaran COVID-19 sangat rentan tertular melalui mata, hidung, dan mulut (WHO, 202ob).

Melawan COVID-19 ini manusia dapat mencegah atau menghindari mulai dari mematuhi protokol kesehatan yaitu dengan menggunakan masker ketika beraktivitas di luar rumah, selalu mencuci tangan dengan sabun atau hand sanitizer ketika setelah bersentuhan dengan barangbarang fasilitas umum atau sesama manusia untuk meminimalisir tertularnya COVID-19. Dengan cara mencuci tangan atau menggunakan hand sanitizer tersebut dapat membunuh kuman atau virus yang menempel di tangan manusia. Sesuai keputusan Menteri Kesehatan RI dalam mencegah dan mengendalikan Covid-19 maka seluruh masyarakat Indonesia dianjurkan untuk menerapkan protokol kesehatan.

Sesuai keputusan Menteri Kesehatan Republik Indonesia Nomor HK.o1.07/MENKES/382/2020 yang menetapkan tentang penerapan untuk menggunakan protokol kesehatan bagi masyarakat saat ditempat maupun saat menggunakan fasilitas umum dalam rangka pencegahan Corona Virus Disease 2019 (COVID-19) dan. Dengan itu diharapkan pemerintahan pusat, pemerintah daerah provinsi, dan pemerintah daerah kabupaten atau kota melakukan pengukuhan dan pengawasan terhadap pelaksanaan protokol kesehatan bagi masyarakat di tempat dan fasilitas umum dalam rangka pencegahan dan pengendalian Corona Virus Disease 2019 (COVID-19), sesuai dengan kewewenangan dari masing-masing petugas dan melibatkan masyarakat (KEMENKES, 2020).

Dusun Saren RT 11 RW 02, Desa Saren, Kecamatan Kalijambe, Kabupaten Sragen termasuk merupakan lingkungan tempat tinggal yang padat penduduk. Lokasi tersebut sering dilalui oleh orang-orang yang berasal dari daerah luar daerah, karena termasuk dekat dengan jalan raya dan salah satu pusat perbelaanjaan di Dusun Saren. Hal ini menjadi rawan akan terjadinya penyebaran COVID-19 apabila tidak adanya masyarakat yang memahami protokol kesehatan dan memahami penanggulangan COVID-19. Dengan melihat situasi Dusun Saren RT 11 RW 02, Desa Saren, Kecamatan Kalijambe, Kabupaten Sragen, peneliti melakukan kegiatan edukasi untuk meningkatkan kesadaran masyarakat agar lebih memperhatikan, menerima dan lebih memahami informasi mengenai langkah-langkah kewaspadaan dan pencegahan infeksi COVID19, serta lebih waspada untuk mematuhi protokol kesehatan, seperti menggunakan masker saat bepergian dengan benar dan mencuci tangan atau memakai disenfektan setelah menyentuh benda-benda di tempat umum.

Setelah melakukan studi pendahuluan teridentifikasi lima isu permasalahan yang muncul yaitu pertama, masalah pendidikan di tunjukkan pada anak-anak di Dusun tersebut yang melaksnakan kegiatan belajar secara online (daring) yang mengakibatkan menurunnya kualitas belajar anak, menurunnya semangat belajar anak, menurunnya pemahaman anak terhadap pelajaran dan meningkatnya stress pada anak serta orangtua selama sistem belajar daring berlangsung. Kedua, masalah kesehatan, yang mana masih ada beberapa warga belum menggunakan masker dengan benar atau bahkan tidak menggunakan masker saat melakukan aktivitas diluar rumah. Seperti yang kita ketahui, bahwasannya penggunaan masker sangat 


\section{JPPM (Jurnal Pendidikan dan Pemberdayaan Masyarakat), 8 (1), 2021 - 51}

Irra Datik Pratiwi, Mila Faila Shofa

penting dalam menjaga diri untuk terhindar dari COVID-19 ini. Kemudian masih kurangnya warga lansia mengenai edukasi penanggulangan COVID-19, Karena kebanyakan bekerja sebagai petani sehingga mereka ketika ke sawah kurang memperhatikan protokol kesehatan dan lebih cenderung tidak memperdulikan hal ini. Ketiga, masalah lingkungan ditunjukkan dari beberapa sampah non-organik yang berada di sekitar Dusun belum terolah dengan baik. Dengan sampahsampah non-organik bisa didaur ulang dan bahkan bisa dijadikan sebagai ketrampilan, sehingga akan lebih ramah lingkungan. Keempat, masalah keagamaan, tidak terlaksanya kegiatankegiatan keagamaan selama COVID-19 seperti kegiatan pengajian, sekolah Madrasah Diniyah tempat belajar baca tulis Al-Qur'an dan ilmu-ilmu agama. Kelima, masalah sosial-ekonomi ditunjukkan oleh warga Dusun Saren menjalankan program provinsi Jawa Tengah yaitu kegiatan Jogo Tonggo bagi-bagi sayur-mayur bagi warga yang membutuhkan yang dicanagkan oleh Bapak Gubernur Jawa Tengah, dengan kegiatan ini maka warga akan terbantu kebutuhan sehariharinya.

Berdasarkan latar isu-isu prioritas diatas, penulis fokus dalam bidang kesehatan yang mana masyarakatnya masih kurang akan hal tentang memakai protokol kesehatan COVID-19. Dalam hal ini saya akan melakukan edukasi COVID-19 di Dusun Saren RT 11 RW o2, Desa Saren, Kecamatan Kalijambe, Kabupaten Sragen dalam melakukan penanggulangan COVID-19 melalui program edukasi pencegahan penyebaran dan penularan COVID-19. Dikarenakan masih kurangnya pemahaman masyarakat terhadap COVID-19 dan penggunaan protokol kesehatan saat melakukan kegiatan ke luar dari rumah masih jarang dilakukan. Dalam mencegah penularan dan penyebaran COVID-19 ini, saya mengedukasi masyarakat dengan memberikan edukasi tentang covid-19 dan cara-cara pencegahan seperti melakukan pembuatan dan penyebaran poster edukasi dengan ditempelkan ditempat-tempat umum, bersosialisasi mengenai COVID-19, memberikan edukasi pentingnya penggunaan protokol kesehatan di tengah pandemi COVID-19 serta mengedukasi langkah-langkah penggunaan protokol kesehatan yang benar dengan membuat edukasi penggunaan masker kain, penggunaan hand sanitizer saat berada di luar rumah, penyemprotan disenfektan untuk membasmi COVID-19, dan pentingnya mencuci tangan yang benar.

Kegiatan edukasi ini bertujuan agar masyarakat setempat mengetahui tata cara penanggulangan COVID-19 (Sulaeman, dkk 2020). Peneliti melakukan kegiatan edukasi dengan cara menyebarkan poster di tempat-tempat umum yang sering dilihat masyarakat desa, mengumpulan beberapa warga untuk diberikan penyuluhan terkait pencegahan covid-19 dengan tetap memperhatikan protocol kesehatan, dan memberikan info-info pencegahan covid19 di wa grup masyarakat Desa Sraten. Edukasi yang dilakukan peneliti seperti menghimbau msyarakat untuk mematuhi protokol kesehatan COVID-19, mengimbau masyarakat supaya meminimalisir kegiatan di luar rumah, dan menjaga imun tubuh serta menjaga kebersihan lingkungan. Sehingga dengan adanya edukasi COVID-19 ini dapat meningkatkan kesadaran masyarakat Dusun Saren RT 11 RW 02, Desa Saren, Kecamatan Kalijambe, Kabupaten Sragen untuk selalu memperhatikan protokol kesehatan demi meminimalisir penyebaran COVID-19 dan paham akan penanggulangannya.

\section{METODE}

Metode yang digunakan dalam penelitian ini adalah metode penelitian kualitatif dengan pendekatan etnografi. Dengan penelitian etnografi ini peneliti melakukan penelitian lapangan pada kondisi masyarakat di Dusun Saren RT 11 RW 02, Desa Saren, Kecamatan Kalijambe, Kabupaten Sragen dengan apa adanya selama pada masa pandemi COVID-19 sekarang ini. Peneliti mengumpulkan data atau informasi secara triangulasi yaitu Peneliti menggunakan observasi pastisipasif, wawancara mendalam, dan dokumentasi untuk sumber data yang sama secara serempak dengan menggabungkan data yang sudah diperoleh peneliti berupa informasi terkait penerapan menjaga diri sesuai protokol kesehatan sesuai anjuran Pemerintahan Republik 


\section{JPPM (Jurnal Pendidikan dan Pemberdayaan Masyarakat), 8 (1), 2021 - 52}

Irra Datik Pratiwi, Mila Faila Shofa

Indonesia selama masa Pandemi COVID-19 demi menjaga kesehatan kita dan terhindar dari COVID-19.

Triangulasi menurut Susan Stainback dalam Sugiyono (2007:330) adalah "The aim is not to determinate the truth about same social phenomenon, rather than the purpose of triangulation is to increase one's understanding of what ever is being investigated." Maka dari itu tringulasi ini tujuannya bukan untuk mencari kebenaran, melainkan untuk meningkatkan pemahaman peneliti terhadap data dan fakta-fakta yang dimiliki (Bachri, 2010).

Analisis data menggunakan analisis interaktif yang meliputi pengumpulan data, penyajian data, reduksi data dan penarikan kesimpulan. Data yang diperoleh peneliti di lapangan melalui wawancara, observasi partisipatif dan dokumentasi direduksi dengan cara merangkum, memilih dan memfokuskan data sesuai dengan tujuan penelitian, data kemudian disajikan setelah proses reduksi. Berdasarkan data berupa pemahaman tentang pencegahan covid-19 disajikan, peneliti membuat kesimpulan yang didukung dengan bukti yang kuat.

\section{HASIL DAN PEMBAHASAN}

Di Indonesia, pandemi ini pertama kali terdeteksi pada pertengahan Maret 2020. Virus ini dapat menular secara mudah melalui tetesan cairan yang berasal dari batuk dan bersin; kontak pribadi seperti melalui sentuhan dan berjabat tangan; menyentuh benda atau permukaan yang telah terkena virus yang kemudian dilanjutkan menyentuh mulut, hidung, maupun mata sebelum mencuci tangan (Dzulfaroh, 2020). Untuk itu dalam rangka mencegah penyebarannya, salah-satu langkah agar dapat memutus rantai penularan virus tersebut adalah mematuhi protokol kesehatan selama pandemi COVID-19 khususnya untuk penduduk yang berada di Desa Saren. Desa Saren merupakan salah satu Desa dalam wilayah Kecamatan Kalijambe, Kabupaten Sragen yang terbagi dalam 9 Dukuh dan 19 RT. Sebagian besar penduduk Dusun Saren Rt 11/ Rw 02 ini pekerjaannya sebagai petani. Berdasarkan pengamatan, beberapa masyarakat sini masih kurang kesadaran penggunaan protokol kesehatan selama pandemi COVID-19 ini. Masih ada beberapa warga yang tidak mempedulikan akan pentingnya penggunaan protokol kesehatan selama keluar dari rumah khususnya bagi para petani. Para petani yang ketika berkebun tidak menggunakan masker.

Kondisi ini perlu diperhatikan lebih khusus karena sangat berbahaya dan penyebaran virus COVID-19 yang semakin hari semakin bertambah dan banyak masyarakat yang mengalami kecemasan akan hal ini. Namun dengan tersebarnya berita-berita yang tidak relevan juga dapat menjadi penghambat dalam penanggulangan virus COVID-19 di Dusun Saren Rt 11/ Rw 02, Desa Saren, Kecamatan Kalijambe, Kabupaten Sragen khususnya. Sedikitnya pengetahuan dan pemahaman masyarakat mengenai informasi seputar virus COVID-19 yang tidak relevan juga dapat menimbulkan dampak sosial yang besar. Upaya yang bisa dilakukan adalah dengan melakukan berbagai kegiatan pencegahan, yaitu dengan mulai memberikan edukasi COVID-19 kepada masyarakat yang berada di Dusun Saren Rt 11/ Rw 02, Desa Saren, Kecamatan Kalijambe, Kabupaten Sragen untuk mendapatkan data dan informasi yang relevan mengenai wabah virus COVID-19 yang ada di Dusun setempat. Edukasi adalah proses pembelajaran yang bertujuan untuk mengembangkan potensi diri pada seseorang dan mewujudkan proses pembelajaran yang baik. Pengetahuan dan pemahaman yang ilmiah, akurat dan dapat dipercaya akan dapat membantu masyarakat untuk mudah melaksanakan himbuan dan arahan pemerintah guna menekan penyebaran COVID-19 di Dusun Saren Rt 11/ Rw 02, Desa Saren, Kecamatan Kalijambe, Kabupaten Sragen.

Sebagaimana atas dasar inilah telah dilakukan kegiatan edukasi COVID-19 untuk meningkatkan pengetahuan masyarakat Dusun Saren RT 11 RW 02, Desa Saren, Kecamatan Kalijambe, Kabupaten Sragen agar dapat menghadapi dan melewati pandemi COVID-19 (Sulaeman \& Supriadil, 2020). Edukasi COVID-19 yang dilakukan tetap menerapkan sistem protokol kesehatan COVID-19 yaitu bersosilisasi secara langsung kepada masyarakat dan sosialisasi dengan menyebarkan poster-poster di tempat-tempat umum. Sosialisasi terpacu pada 


\section{JPPM (Jurnal Pendidikan dan Pemberdayaan Masyarakat), 8 (1), 2021 - 53}

Irra Datik Pratiwi, Mila Faila Shofa

penggunaan alat-alat protokol kesehatan yaitu masker, cuci tangan dengan sabun dan hand sanitizer. Masyarakat juga diberikan pemahaman edukasi COVID-19 dari sumber terpercaya, sehingga masyarakat mendapatkan informasi yang valid dan kemudian bisa di terapkan pada kesehariannya.

Edukasi COVID-19 yang pertama yaitu edukasi menggunakan masker dengan benar. Penggunaan masker dengan benar merupakan salah satu upaya pencegahan COVID-19. Di tengah pandemi COVID-19, masker sangat diperlukan jika masyarakat akan berpergian keluar rumah. Memakai masker tidak hanya untuk orang sakit saja, tetapi orang sehatpun juga wajib pakai masker jika keluar dari ruma pada masa pandemi COVID-19. Edukasi penggunaan masker ini saya mempraktikan dengan dua jenis masker, yang pertama masker sekali pakai dan masker yang bisa dipakai lagi (masker kain). Bahwasannya jika masker sekali pakai itu tidak boleh dipakai lagi dan langsung dibuang ditempat sampah yang tertutup atau dibakar langsung. Sedangkan masker yang bisa dipakai ulang (masker kain) itu boleh digunakan lagi apabila sudah dicuci dengan bersih. Mencuci masker kain dengan benar itu dengan merendam air panas 50$60^{\circ} \mathrm{C}$, air panas ini berfungsi untuk membunuh kuman penyakit yang menempel pada kain masker, kemudian bilas masker dengan air mengalir, selanjutnya keringkan masker kain (WHO, 2020a).

Sedangkan saat menggunakan masker sekali pakai langkah-langkahnya sebelum memakai masker bersihkan tangan dengan hand sanitizer berbahan dasar alkohol atau sabun dan air, selanjutnya tutup mulut dan hidung kemudian pastikan tidak ada celah antara wajah dan masker. Kemudian hindari menyentuh masker, jika menyetuhnya bersihkan tangan dengan hand sanitizer berbahan dasar alkohol atau sabun dan air dan terakhir ganti masker dengan yang baru setelah terasa lembab dan jangan gunakan kembali masker sekali pakai. Langkah dalam membuang masker yaitu, pertama lepas masker dari belakang menggunakan talinya dan jangan menyentuh bagian depan masker. Kedua segera buang masker di tempat sampah yang tertutp. Ketiga bersihkan tangan dengan hand sanitizer berbahan dasar alkohol atau sabun dan air (WHO, 202ob).

Dalam edukasi ini peneliti mengedukasi keluarga terlebih dahulu, baru kemudian warga masyarakat sekitar saya, mulai dari anak-anak, remaja, dan ibu-ibu. Dikarenakan banyak sekali msayarakat setempat yang masih kurang pengetahuan tentang penggunaan masker dengan benar, misalnya saja penggunaan masker yang dibuka-tutup sembarangan pada saat ditempat umum, menggunakan masker dibawah hidung sehingga yang ditutup pakai masker hanya mulut saja. Sebagimana dikatankan juga oleh (Faisal \& Susanto, 2017) dengan penggunaan masker yang salah maka akibatnya juga fatal dan menyebabkan virus tetap bisa masuk lewat hidung ataupun mulut. Tanggapan dan komentar masyarakat beserta anak-anak tentang kegiatan ini sangat positif. Dalam kegiatan sosialisasi masker ini saya juga memberikan masker bagi yang belum memakai masker.

Edukasi COVID-19 yang kedua yaitu edukasi melalui poster. Poster ini berbentuk gambar atau tulisan di atas kertas dan dipasang di tempat umum, pemberitahuan poster berisi himbauan kepada masyarakat tentang sesuatu hal (Kusrini, 2008). Edukasi menggunakan poster ini dengan membuat poster dan menyebarluaskan poster kemasyarakat dan di tempelkan di tempat-tempat umum. Poster-poster yang saya buat yaitu poster cuci tangan dengan sabun, Poster cuci tangan dengan hand sanitizer saat bepergian diluar rumah, poster cara menggunakan masker, Poster etika saat batuk, poster memakai masker bukan hanya untuk orang sakit saja, poster cegah COVID-19 pesan untuk petani, poster manfaat aktivitas fisik selama COVID-19, poster menjaga kebersihan lingkungan, dan poster jaga kebersihan masjid dan mushalla dari COVID-19. Posterposter ini saya ambil dari Lembaga Kementrian Kesehatan Republik Indonesia dan Lembaga Gerakan Masyarakat Sehat (GERMAS). Masyarakat sekitar sangat mendukung dengan penempelan poster-poster ditemapt umum ini karena dengan poster-poster ini bisa menjadi pengingat sesuai informasi yang terkandung dalam poster tersebut.

Edukasi COVID-19 yang ketiga yaitu edukasi penggunaan hand sanitizer. Hand sanitizer juga bisa di sebut dengan antiseptic yang terbuat dari bahan kimia untuk mencegah multiplikasi 


\section{JPPM (Jurnal Pendidikan dan Pemberdayaan Masyarakat), 8 (1), 2021 - 54}

Irra Datik Pratiwi, Mila Faila Shofa

organisme pada permukaan tubuh, dengan cara membunuh mikroorganisme tersebut atau menghambat pertumbuhan dan aktivitas metaboliknya. Hand sanitizer atau antiseptik yang sering digunakan biasayanya yang mengandung alkohol. Alkohol ini banyak yang menggunakan sebagai antiseptic kulit karena bisa menghambat pertumbuhan suatu bakteri pada permukaan tubuh kita (Desiyanto \& Djannah, 2013). Maka dari itu dimasa Pandemi COVID-19 ini lita pelu menggunakan antiseptik. Penggunaan antiseptik merupakan salah satu upaya pencegahan COVID-19. Di tengah pandemi COVID-19, antiseptik sangat diperlukan jika masyarakat berpergian keluar rumah. Penggunaan antiseptik ini kurang lebih dilakukan selama 60 detik (WHO, 202ob). Anak-anak sangat antusias dalam mengikuti kegiatan ini dan juga ibu dari anak-anak mendampingi untuk mengikuti kegiatan ini. Dalam kegiatan cuci tangan dengan hand sanitizer ini saya memodifikasi langkah-langkah mencuci tangan dengan dinyanyikan sehingga mudah dihafal dan anak-anak lebih antusias untuk melakukannya.

Edukasi COVID-19 yang keempat yaitu edukasi mencuci tangan dengan sabun. Mencuci tangan adalah salah satu tindakan budaya hidup bersih dengan membersikan jari-jemari menggunakan air dan sabun supaya bersih (Desiyanto \& Djannah, 2013). Hal itu sesuai dengan penelitian yang dilakukan (Mustikawati, 2017) cuci tangan yang baik itu sebaiknya memakai sabun yang tidak mengandung anti mikroba atau sabun antiseptic yang mengandung anti mikroba. Di tengah pandemi COVID-19, kita harus mencuci tangan sesering mungkin setelah bepergian dan menyentuh barang-barang di tempat umum merupakan salah satu upaya pencegahan atau meminimalisir penularan COVID-19. Cuci tangan dengan menggunakan air dan sabun jika dilakukan secrara tepat dan benar maka hal ini dapat mencegah kita mudah terjangkit suatau penyakit karena suatu bakteri.

Langkah-langkah mencuci tangan dengan benar yaitu, pertama basahi tangan dan gosokgosok sabun pada kedua telapak tangan meliputi seluruh permukaan tangan dengan arah memutar dan air mengalir. Kedua usap tangan dengan mengosok-gosok kedua punggung tangan. Ketiga gosok sela-sela jari tangan. Keempat membersihkan ujung jari dengan posisi saling mengunci. Kemudian yang kelima gosok dan putar kedua ibu jari secara bergantian. Keenam atau terakhirletakkan ujung jari ke telapak tangan kemudian gosok perlahan. Bilas dengan air bersih dan keringkan. Lakukan cuci tangan selama minimal 6o detik atau 1 menit (Mawuntu et al., 2018). Sering mencuci tangan dengan cara yang baik adalah kunci untuk mencegah penyebaran mikroorganisme (juga dikenal sebagai mikroba atau kuman) yang menyebabkan penyakit umum, dan pembersihan secara teratur permukaan tangan dapat menghilangkan partikel kotoran dan makanan di mana kuman dapat tumbuh. Mencuci tangan dengan sabun dan air lebih baik dari pada menggunakan hand sanitizer (Desiyanto \& Djannah, 2013). Setelah kegiatan ini saya mengevaluasi dengan meminta tanggapan ke masyarakat beserta anak-anak. Mereka merasa terbantu dengan kegiatan cuci tangan ini yang mana langkahlangkah mencuci tangan dimodifikasi dengan dinyanyikan sehingga mudah dihafal dan anakanak lebih antusias untuk melakukannya.

Edukasi COVID-19 yang kelima yaitu penanaman tanaman sehat jahe merah. Jahe ini merupakan salah satu tanaman herbal yang mudah dikenal masyarakat. Tanaman jahe ini memiliki beberapa jenis salah satunya jahe merah. Jahe merah merupakan tanaman herbal yang kerap dimanfaatkan untuk meningkatkan daya tahan tubuh, mengatasi berbagai kondisi mulai dari mual, batuk, nyeri sendi, hingga nyeri akibat terapi kanker. Hal ini karena jahe merah mengandung zat anti radang dan antibakteri sehingga membantu mencegah infeksi virus dan bakteri (Aryanta, 2019). Sedangkan (Rezkisari, 2018) menyatakan bahwa jahe merah merupakan bahan obat herbal yang berkhasiat untuk meredakan batuk dan radang tenggorokan, menurunkan kadar kolesterol jahat, meredakan sakit kepala, mengatasi rematik, menurunkan berat badan, menjaga kesehatan jantung, mengatasi mual dan masalah pencernaan, mencegah radang usus, meningkatkan sistem kekebalan tubuh, dan menyembuhkan penyakit asma

Menanam tanaman merupakan kegiatan yang menggabungkan aktivitas fisik, interaksi sosial, paparan alam dan sinar matahari sehingga dapat membuat tubuh dan pikiran bisa merasa lebih segar dan rileks. Lebih lanjut menanam tanaman juga memiliki peran penting dalam 


\section{JPPM (Jurnal Pendidikan dan Pemberdayaan Masyarakat), 8 (1), 2021 - 55}

Irra Datik Pratiwi, Mila Faila Shofa

meningkatkan kesehatan mental, yaitu menurunkan tingkat kecemasan dan depresi, meningkatkan suasana hati, menambah aktivitas fisik, dan lain-lain (Fitrianti, 2020). Budidaya tanaman jahe ini saya memilih menggunakan media polybag karena merupakan metode yang termudah untuk membantu warga menanam jahe dihalaman rumahnya. Membudidayakan tanaman jahe sangat dibutuhkan oleh warga setempat karena jahe memiliki berbagai manfaat yang menyehatkan tubuh. Hal ini sangat cocok dengan kondisi saat ini dimana kita perlu untuk lebih menjaga kesehatan tubuh. Kegiatan menanam jahe ini saya harapkan bisa bermanfaat untuk menjaga kesehatan tubuh masyarakat yang berada di Dusun Saren RT 11 RW 02, Desa Saren, Kecamatan Kalijambe, Kabupaten Sragen. Masyarakat beranggapan bahwa kegiatan ini baik dan positif. Banyak warga yang mengatakan bahwasannya dirumah belum ada tanaman jahe dan akan merawat tanaman jahe tersebut dengan baik.

Edukasi COVID-19 yang keenam yaitu penyemprotan disenfektan. Menurut KBBI, disinfektan merupakan bahan kimia yang digunakan untuk membasmi kuman penyakit. Di tengah pandemi COVID-19, pemerintah dan masyarakat memanfaatkan cairan disenfektan untuk mencegah penyebaran COVID-19 melalui benda-benda mati. Sehat merupakan keinginan kita semua, tubuh masing-masing orang itu memiliki taraf kekebalan sendirisendiri, dengan suatu cara tertentu tubuh seseorang akan mampu bertahan untuk melawan suatu penyakit. Mencegah penyakit dan penyebarannya dapat dilakukan mulai dari diri sendiri dan lingkungan sebagai sarana untuk mengurangi penyebaran penyakit karena mikroorganisme. Di tengah kebijakan ekonomi new normal, tempat ibadah, tempat-tempat umum, dan lingkungan sekitar mulai dipadati masyarakat. Untuk mengantisipasi penyebaran COVID-19, maka diperlukan penyemprotan disinfektan secara berkala. Peneliti Kimia dari Lembaga Ilmu Pengetahuan Indonesia (LIPI), Dr. Joddy Arya Laksmono mengungkapkan bahwa dalam membuat cairan disenfektan sendiri, sebenarnya hanya dibutuhkan dua bahan utama, yakni air yang di campur dengan cairan pemutih pakaian atau pembersih lantai yang mengandung konsentrasi bahan aktif yang sesuai untuk digunakan sebagai disenfektan, salah satunya adanya Wipol Pembersih Lantai Jeruk yang mengandung bahan aktif Ethoxylated alchocol (3\%) dan Benzalkonium chloride (1,25\%). Pada setiap 1 liter air, cairan Wipol yang digunakan adalah $50 \mathrm{ml}$ (Bramasta, 2020).

Melakukan kegiatan penyemprotan bersama masyarakat Dusun Saren Rt 11/Rw 02, Desa Saren, Kecamatan Kalijambe, Kabupaten Sragen. Tanggapan dan komentar masyarakat tentang kegiatan ini sangat positif. Mereka merasa mendapatkan bantuan yang besar dengan adanya kegiatan penyemprotan karena mereka menyadari bahwa kegiatan ini merupakan kegiatan yang bagus untuk membersihkan lingkungan dari virus dan kuman yang ada.

Kegiatan pengabdian Kuliah Kerja Nyata (KKN) ini kemudian ditutup dengan kegiatan berpamitan dengan Kepala Desa dan Kepala Dusun Serta Masyarakat yang berada di Dusun Saren Rt 11/Rw 02, Desa Saren, Kecamatan Kalijambe, Kabupaten Sragen. Dalam kegiatan berpamitan ini tidak lupa saya mengucapkan terimakasih kepada pihak-pihak yang telah membantu memperlancar kegiatan pengabdian Kuliah Kerja Nyata (KKN) dimasa pandemik COVID-19 ini. Meskipun dalam masa pandemi COVID-19, kami tetap mengabdi.

\section{SIMPULAN}

Masih sangat minim pemahaman dan kesadaran masyarakat Dusun Saren Rt 11/ Rw 02, Desa Saren, Kecamatan Kalijambe, Kabupaten Sragen yang mematuhi protokol kesehatan saat beraktivitas diluar rumah. Berdasarkan permasalahan tersebut, penulis melakukan pengabdian pada masyarakat melalui kegiatan Kuliah Kerja Nyata (KKN) IAIN Surakarta edisi COVID-19 dengan mengedukasi masyarakat setempat melalui edukasi protokol kesehatan, penyemprotan disenfektan, dan penanaman tanaman sehat, serta penyebaran poster. Maka dengan pemberian edukasi COVID-19 penulis berharap masyarakat setempat mendapatkan pencerahan dan penjelasan yang lebih jelas mengenai virus COVID-19 yang sedang mewabah di berbagai Negara termasuk Indonesia khususnya Dusun Saren Rt 11/ Rw 02, dan lebih memahami informasi 


\section{JPPM (Jurnal Pendidikan dan Pemberdayaan Masyarakat), 8 (1), 2021 - 56}

Irra Datik Pratiwi, Mila Faila Shofa

mengenai langkah-langkah kewaspadaan maupun pencegahan infeksi Covid-19 dengan baik serta lebih waspada COVID-19 dan mematuhi protokol kesehatan setelah dilakukan edukasi COVID-19. Melalui edukasi yang dilakukan oleh peneliti di Dusun Saren Rt 11/ Rw o2 masyarakat mengalami banyak perubahan mulai dari masyarakat yang pada awalnya kurang memperhatikan protokol kesehatan menjadi lebih waspada COVID-19 dan mematuhi protokol kesehatan setelah dilakukan edukasi COVID-19 serta masyarakat lebih menerima dan menjadi lebih memahami informasi mengenai langkah-langkah kewaspadaan dan pencegahan infeksi Covid-19 dengan baik. Hasil penelitian ini sesuai dengan penelitian Priyantoro (2020) yang menyebutkan bahwa kegiatan sosialisasi dan edukasi telah meningkatkan pemahaman masyarakat dalam mitigasi bencana dengan prosentase mencapai $96 \%$.

\section{DAFTAR PUSTAKA}

Aji, A. M., \& Habibaty, D. M. (2020). Fatwa Majelis Ulama Indonesia Tentang Penyelenggaraan Ibadah Dalam Situasi Terjadi Wabah Covid-19 Sebagai Langkah Antisipatif dan Proaktif Persebaran Virus Corona Di Indonesia. Jurnal Sosial E Budaya Syar-I, 7(8), 673-686. https://doi.org/10.15408/sjsbs.v7i8.17059

Amalia Zhahrina. (2020). Menyerang Organ, Bagaimana Proses Virus Corona Menginfeksi Manusia? Kompas.Com. https://www.google.com/url?sa=t\&source=web\&rct=j\&url=https://amp.kompas.com/sain s/read/2020/02/17/130300723/menyerang-organ-bagaimana-proses-virus-coronamenginfeksi-manusia-\&ved=2ahUKEwiey9qP-PsAhXlmuYKHU9oDZUQFjAJegQIBBAB\&usg=AOvVaw239aoaSWLCo51tsGQgGo

Amany, D., \& Desire, A. (2020). Pembelajaran Interaktif berbasis Gamifikasi guna Mendukung Program WFH pada saat Pandemik COVID-19. Karya Tulis Ilmiah (KTI) UIN Sunan Gunung Djati Bandung, 48-55.

Aryanta, I. W. R. (2019). Manfaat Jahe untuk Kesehatan. Jurnal Widya Kesehatan, 1(2), 39-43.

Bachri, B. S. (2010). Meyakinkan Validitas Data Melalui Tringulasi pada Penelitian Kualitatif. Jurnal Teknologi Pendidikan, 10(1), 46-62.

Bramasta, D. B. (2020). Membuat Disenfektan Sendiri: Cara, Bahan, dan Hal yang Harus Diperhatikan. Kompas.Com. https://www.kompas.com/tren/read/2020/03/30/054700165/membuat-disinfektansendiri--cara-bahan-dan-hal-yang-harus-diperhatikan?page=all

Cao, Z., Li, T., Liang, L., Wang, H., Wei, F., Meng, S., Cai, M., Zhang, Y., Xu, H., Zhang, J., \& Jin, R. (2020). Clinical characteristics of Coronavirus Disease 2019 patients in Beijing, China. Journal.Pone.0234764, 1-7. https://doi.org/10.1371/journal.pone.0234764

Desiyanto, F. A., \& Djannah, S. N. (2013). Efektivitas Mencuci Tangan Menggunakan Cairan Pembersih Tangan Antiseptik (Hand sanitizer) terhadap Jumlah Angka Kuman. Jurnal Kesehatan Masyarakat, 7(2), 75-82.

Dzulfaroh, A. N. (2020). Cara Penularan Virus Corona dan Alasan Pentingnya Social Distancing. Kompas.Com. https://www.kompas.com/tren/read/2020/03/19/064600465/carapenularan-virus-corona-dan-alasanpentingnya-social-distancing?page=all

Faisal, H. D., \& Susanto, A. D. (2017). Peran Masker atau Respirator dalam Pencegahan Dampak Kesehatan Paru Akibat Polusi Udara. Jurnal Respirasi, 3(1).

Fitrianti, A. (2020). Manfaat Menanam Tanaman untuk Kesehatan Mental selama Pandemi COVID-19. Good Doctor. https://www.gooddoctor.co.id/tips-kesehatan/mental/manfaatmenanam-tanaman-untuk-kesehatan-mental-selama-pandemi-covid-19/

Kemendesa. (2020). Protokol Relawan Desa Tanggap Lawan COVID-19. Kementerian Desa, Pembangunan Daerah Tertinggal, Dan Transmigrasi. https://www.kemendesa.go.id/berita/view/detil/3221/protokol-tanggap-covid-19-iniarahan-gus-menteri-pada-relawan-desa

Kemendikbud. (2020). Perluas Akses Belajar di Masa Covid-19, Mendikbud Luncurkan Program 
Belajar dari Rumah. Kementerian Pendidikan Dan Kebudayaan. https://www.kemdikbud.go.id/main/blog/2020/o4/perluas-akses-belajar-di-masacovid19-mendikbud-luncurkan-program-belajar-dari-rumah

KEMENKES. (2020). Keputusan menteri kesehatan republik indonesia nomor hk.01.07/menkes/413/2020 tentang pedoman pencegahan dan pengendalian.

Kusrini, I. A. (2008). Bahasa Indonesia. Jakarta: Yudhistira Ghalia Indonesia.

Mawuntu, A. H. P., Tumbal, J., Pontoh, M., \& Mewo, Y. (2018). Evaluasi Efektifitas Prosedur Cuci Tangan pada Operator Fungsi lumbal Di Bagian Neurologi RSUP R.D. Kandou Manado. Jurnal Sinaps, 1(1), 47-66.

Mulyani, Wi. (2020). Edukasi COVID-19 Melalui Program KKN UNS untuk Mewujudkan Desa Kedungwinangun SIgap, Cerdas, dan Sehat. Jurnal Penelitian Dan Pengabdian, 1(1), 365000.

Mustikawati, I. S. (2017). Perilaku Cuci Tangan Pakai Sabun Studi Kualitatif pada Ibu-Ibu di Kampung Nelayan Muara Angke Jakarta Utara. Jurnal ARKESMAS, 2(1).

Nasruddin, R., \& Haq, I. (2020). Pembatasan Sosial Berskala Besar ( PSBB ) dan Masyarakat Berpenghasilan Rendah. Jurnal Sosial Dan Budaya Syar-I, 7(7), 639-648. https://doi.org/10.15408/sjsbs.v7i7.15569

Priyantoro, dkk. (2020). Pemberdayaan masyarakat Pekon Negeri Ratu Tenumbang dalam mewujudkan wilayah tanggap bencana. Jurnal Pendidikan dan Pemberdayaan Masyarakat Vol. 7 No. 2

Rezkisari, I. (2018). Manfaat Jahe Merah untuk Kesehatan. Republika.Co.Id. https://m.republika.co.id/berita/pjrs4z328/manfaat-super-jahe-merah-untuk-kesehatan

Sulaeman, \& Supriadil. (2020). Peningkatan Pengetahuan Masyarakat Desa Jelantik Dalam Menghadapi Pandemi Corona Virus Diseases-19 (COVID-19). Jurnal Hasil Pengabdian Dan Pemberdayaan Kepada Masyarakat, 1(1), 12-17.

Telaumbanua, D. (2020). Urgensi Pembentukan Aturan Terkait Pencegahan Covid-19 di Indonesia. Jurnal Pendidikan, Sosial, Dan Agama, 12(1), 59-70.

WHO. (2020a). Anjuran mengenai penggunaan masker dalam konteks COVID-19. World Health Organization.https://www.google.com/url?sa=t\&source=web\&rct=j\&url=https://www.eur o.who.int/en/health-topics/health-emergencies/coronavirus-covid19\&ved=2ahUKEwiPlJvDs_TsAhXj6XMBHRırAGUQFjAAegQIAxAC\&usg=AOvVawıpMpın umUsK-4cS6WSKKZo

WHO. (2020b). WHO announces COVID-19 outbreak a pandemic' World Health Organzation Regional Office for Europe. http://www.who.int/en/health-topics/healthemergencies/coronavirus-covid-19/news/news/2020/3/who-announces-covid-19outbreak-a-pandemic 